\title{
Antecedents of Growth in Higher Education Institutions of North Cyprus: Resource-Based Approach
}

\author{
Mehmet Ali Ekemen (Corresponding author) \\ European University of Lefke, Faculty of Economics and Administrative Sciences, \\ Department of Business Administration, Gemikonağ1, 99728, North Cyprus \\ Tel: 90-392-660-2000Ｅ-mail: mekemen@eul.edu.tr
}

\begin{abstract}
Gözde İnal Cavlan
European University of Lefke, Faculty of Economics and Administrative Sciences, Department of Business Administration, Gemikonağ1, 99728, North Cyprus

Tel: 90-392-660-2000Ｅ-mail: ginal@eul.edu.tr
\end{abstract}

Received: February 8, 2016 Accepted: February 11, 2016 Published: March 7, 2016

doi:10.5296/bms.v7i1.8995 URL: http://dx.doi.org/10.5296/bms.v7i1.8995

\begin{abstract}
This study aims to reveal the antecedents of growth in Higher Education Institutions of North Cyprus, using Resource Based Approach. Research in this field is limited to developed economies and there is a need for more research in the developing country settings. North Cyprus is a unique location for this study since it is a developing country which is geographically located in between Europe, Africa and Middle East harmonizing several different cultures in its unique settings. An explanatory research design was adopted using a questionnaire survey to collect data and test the hypotheses. Data was collected from 343 respondents, consisting of 172 administrative and 171 academic staff, in five universities which have 10 years of history in higher education sector. The results of the study showed that Marketing resources, Human resources, Research and Development resources, Organizational resources and accessibility of these resources have been shown to positively influence the university growth.
\end{abstract}

Keywords: Growth, Resource-Based View, University, North Cyprus 


\section{Introduction}

In an economic system, higher education institutions are placed in a strategic position since they produce knowledge and train people for their designated careers. In the contemporary world, universities contribute to the development of the societies in science and technological fields. In addition to training people and producing knowledge, they have been forming close and inevitable relations with society by setting up economic and social interactions. As the key generators of economic activity, universities have an important role in a society. Therefore, the relationship between the university and the society is becoming an increasingly popular issue as they are inseparable and a focal point in the community (Perry \& Wiewel, 2005, p.3).

The presence of a university has implications for economic development on the region in which it is located. Contemporary universities are large complexes that employ thousands of workers, occupy large areas of land and consume large budgets. They are more similar to a business complex, running specialized research centers and even hospitals, housing and residential accommodation, sports, catering and cultural facilities and sometimes associated with commercial ventures such as a science or a research park. Thus, as a large scale consumer of inputs such as labor, goods and services and generators of outputs such as skills, know-how and local attractiveness, the university becomes a major factor in local economic development. Even without a proactive, explicit role in promoting local economic activity, the results of its policies and decisions are likely to have large impacts on its local economy (Siegfried et al., 2007).

The main objective of this study is to reveal the resource based factors that affect the growth of the Higher Education Institutions (i.e. universities) in North Cyprus. In order to suggest a model that would help universities to grow in the North Cyprus setting, we aim to identify the growth factors pertaining to universities in North Cyprus. There is a need for more research on this topic especially in different country settings to explore the application of theories in developing country settings rather than developed economies (Wang \& Lo, 2002). North Cyprus is a unique location for this study since it is a developing country which is geographically located in between Europe, Africa and Middle East harmonizing several different cultures in its unique settings.

The study aims to answer two main research questions;

- What are the resource based factors utilizing the growth of higher education institutions in North Cyprus?

- How do these factors affect the growth of higher education institutions? Can a pattern for this relationship be identified?

The paper is structured as follows; firstly, the Higher Educational Industry in North Cyprus is described, then the theoretical background of growth and Resource Based View (RBV) is provided by investigating the resources; human resources, operational resources, marketing 
resources, financial resources, research \& development resources, organizational resources which are contributing to the growth of higher education institutions. The methodology of study is then explained. Finally, the findings and analysis of the study is presented with key implications.

\subsection{Higher Education Industry in North Cyprus}

Cyprus Island is a small country situated in a very dynamic regional location on the Eastern Mediterranean. In 1974, Cyprus Island was divided into two parts. Turkish Cypriots live on the northern part of the island and therefore established their economy on the north and Greek Cypriots live on the southern part of the island and established their economy on the south (Republic of Cyprus, 1999). In 1983, Turkish Republic of Northern Cyprus (TRNC) was established in northern part, in which forms 36 percent of island (Katırcıoğlu, 2010).

TRNC economy carries special features of small developing island economy with its population about 286,257 (SPO, 2011) and 15,302 US \$ per capita income (SPO, 2013). Although, small island economies have special constraints that restrict their development pace, the service industry in North Cyprus has gained significance in 1980s and onwards.

Higher education sector makes one of the most important industries in North Cyprus by making significant contribution to the economy. It constitutes 40 percent of North Cyprus economy (Washington Times, 2014). By the 1990s, there has been a significant growth in the demand for higher education (Katırcığlu, 2010). The initial demand came from students in Turkey and then from students in different countries such as Africa and Middle East. Currently, there are 11 universities operating in North Cyprus with a total number of 63,765 students of which 34,206 are from Turkey, 12,505 are from Northern Cyprus, and 17,054 are from other 114 countries (Katırcıoğlu, 2010; Washington Times, 2014).

Consistent with the purpose of this study, the research is conducted with academic and administrative staff of five local universities which have minimum 10 years of history in higher education sector of North Cyprus; namely Eastern Mediterranean University (EMU), Near East University (NEU), European University of Lefke (EUL), Girne American University (GAU) and Cyprus International University (CIU).

\section{Growth}

The theories and models that are potentially helpful for explaining firm growth include industrial organization economics, evolutionary theories, and business strategy models (Bhide, 2000). Most studies on firm growth, particularly those published recently, have focused on the factors influencing firm growth. Various factors have been hypothesized and/or empirically tested as directly and/or indirectly influencing firm growth. These include individual-level factors such as founder's education, experience, and growth aspiration (Wiklund \& Shepherd, 2003); organization-level factors such as firm-level resources (Bruton \& Rubanik, 2002; Mishina et al., 2004) and strategies (Baum et al., 2001; Thornhill, 2006); and macro-level factors such as market/environment conditions (Park \& Bae, 2004; Robinson 
\& McDougall, 2001) and economic policy (Riding \& Haines, 2001).

Studies on growth have made important contributions to theory development and management practice. However, the antecedents considered in these studies are so diverse that there is little agreement on the finite and definitive set of factors affecting firm growth (Delmar et al., 2013).

Several researchers have made various classifications of determinants of firm growth (Smallbone \& Massey, 2012). For Example, Gibb and Davies (1990) explained that firm growth can be categorized as growth approaches as personality dominated approaches, organization development approaches, business management approaches, and sectoral and broader market led approaches. O'Farrell and Hitchens (1988) suggested four main theories for firm growth; the industrial economics approach, the stochastic model, the stage models and strategic management perspective. Finally, Storey (1994), argued that the characteristics of the owner/manager, firm characteristics and managerial activities are the key factors that affect the growth of a firm.

Having different determinants for firm growth is partly because of the way growth has been conceptualized and operationalized. Varying ways, such as relative/absolute growth or sales/employment/asset/profit growth; over varying time spans (e.g., one, three, or five years) have been used to conceptualize and measure firm growth (Delmar et al., 2013; Wiklund \& Shepherd, 2005). Researchers have found limited concurrent validity among different growth measures (Wiklund \& Shepherd, 2005) and discovered that using different growth measures yields contradictory conclusions (Davidsson \& Wiklund, 2000). Therefore, it may not always be possible to compare and integrate findings from different studies (Wiklund, 1999; Wiklund $\&$ Shepherd, 2005).

The current study aims to extend Penrose's (1959) theory of firm growth by looking into the growth process, and by identifying key mechanisms of firm growth. In so doing, it is important to acknowledge Penrose's original theoretical positions, which is known as Resource-Based view of the firm (in particular, the firm as a resource system).

\section{Resource-Based View}

Resource Based View (RBV) is the most significant framework for understanding strategic management (Barney et al., 2001; Carmeli \& Tishler, 2004a; Dhanaraj \& Beamish, 2004; Khatri, 2000). The RBV of the firm overcomes the bias in the mainstream strategic management literature by stressing the importance of firm-specific resources that can provide competitive advantage to an organization on a sustainable basis (Khatri, 2000, p. 337).

According to Dhanaraj and Bheamish (2004), RBV focuses on the main issue of how outstanding performance can be obtained in comparison to other businesses operating in the same market, and assumes that outstanding performance results from obtaining and exploiting unique resources of the business. With the combination of use of practices, techniques, firms' specific capabilities and assets, firms have the RBV has made it possible 
for them to compete and obtain sustained competitive advantage (McWilliams \& Siegel, 2011; Penrose, 1959; Teng, 2007). Hart \& Dowell (2011) supports the above by arguing that RBV's focus is on factors internal to the firm that in return leads to sustained competitive advantage. The RBV focused mainly on firm's own decisions and capabilities instead of its environment (Hart \& Dowell, 2011; Hoskisson et al., 1999). Based on the RBV of the firm, in order to innovate, keep up with the changing market environment, and therefore achieve competitive advantage, a business needs to develop, incorporate and reconfigure its skills, capabilities and abilities (Lisboa et al., 2011).

Although the number of empirically tested studies on RBV has been increasing, it has been argued that more empirical research is needed to identify the multidimensionality of performance to also estimate the influence of a collection of resources on the performance of firms from different industries (Carmeli \& Tishler, 2004a).

Penrose (1959) defined a firm as "a collection of physical and human resources" and pointed to the heterogeneity of these resources (Dhanaraj \& Beamish, 2004, p. 9). Another definition provided to resource is "anything that can be thought of as a strength or weakness" of the firm (Dhanaraj \& Beamish, 2004, p. 172). Furthermore, Khatri (2000, p. 337) referred to various definitions of resources based on different researchers; one definition presented is 'anything that could be thought of as strength or weakness of a given firm which include tangible and intangible assets' (Wernerfelt, 1984), another definition is resources are 'skills, organizational routines and processes' (Barney, 1991). Hart \& Dowell (2011, p. 1465) state that 'a resource is something that a firm possesses, which can include physical and financial assets as well as employees' skills and organizational (social) processes. RBV proposed that to gain sustainable competitive advantage, a resource must be valuable, rare, and not imitable supported by tacit skills or socially complex organizational processes and imperfectly non-substitutable (Barney, 1991).

Studies conducted on RBV of the firm grouped resources into different categories as financial, physical, human capital and organizational (Power \& Dougall, 2005).

\subsection{Accessibility of Resources}

The availability of resources in terms of quantity and quality is extremely important on the firm's behavior because these resources are needed for the organizational processes (Grant, 1991). Chandler \& Hanks (1994) emphasize importance of availability of resource-based capabilities for ventures' survival and growth.

The quality and quantity of resources available to the firm inevitably affect its growth rate (Covin \& Slevin, 1997; Gibb \& Davies, 1990). Especially having access to financial resources is crucial. Financial resources provide access to other types of resources (Wiklund $\&$ Shepherd, 2003b). However, not all resources are financial. There are managerial resources as well. The managerial resources are mainly time and knowledge about the management and growth of firms. The firm may also suffer from absence of these managerial resources (Gibb \& Davies, 1990). 
The firm should have access to valuable, rare and inimitable resources. It should also have the ability to develop a strategy to align these resources with opportunities (Barney, 1991; Chrisman et al., 1999). According to Chrisman et al. (1999) having access to resources is an intangible asset and it is an important contributor to new venture success. The intangible assets that the manager should have access to, are capital markets, distribution channels, labor markets, suppliers and raw materials (Chrisman et al., 1999).

In literature, the availability of especially financial resources is found to be related to firm growth (Brown, 1996; Covin \& Slevin, 1991; Surroca et al., 2010). If there are a variety of resources available to the firm, then the firm can apply the desired strategies (Brown, 1996). The availability of financial, physical and human resources is proposed to enhance strategies such as innovation (Galende \& De la Fuente, 2003; Miller \& Friesen, 1982). Depending on the firm's resources, the type of strategy will differ. In order to gain competitive advantage, firms have to employ strategies and these strategies are affected by the resource availability (Chan et al., 2004; Lumpkin \& Dess, 2001). Therefore, resource availability indirectly affects the growth of the firms.

There are various set of items that are used to measure resource-based competencies of businesses, including financial resources, human resources, organizational resources and technological resources (Chandler \& Hanks, 1994; Greene et al., 1997). Those businesses that mobilize more resources tend to be more successful (Castrogiovanni, 1991; Chandler \& Hanks, 1994). Edelman et al.'s (2005) paper referred to Greene \& Brown's (1997) study arguing that "each combination of growth and innovation requires different resource combinations such as human, social, physical, financial or organizational" (p. 363). A firm's growth is dependent on the manager's or managerial team's ability to coordinate resources, and growth happens when manager's expectation of the firm and the firm having access to the suitable resources interacts (Edelman et al., 2005; Penrose, 1959). Therefore, we expect:

$H_{1}$ : The accessibility of resources has significant positive impact on the growth of higher education institution.

\subsection{Human Resources}

Human resources (henceforth HR) of an organization are considered as a strategic resource by resource-based view (Carmeli \& Tishler, 2004b). The human resources are important for the organization because they are valuable, rare, and inimitable and have no substitutes (Khatri, 2000). To be successful, the small firm has to build capabilities to attract and retain quality employees (Barringer et al., 2005; Lussier \& Pfeifer, 2001). The HR system can help an organization become more effective and gain competitive advantage (Becker \& Huselid, 1998; Bowen \& Ostroff, 2004). Research shows that human resources management capabilities are influential on the success of firms (Buller \& Mc Evoy, 2012; Lussier \& Pfeifer, 2001). This influence like other capabilities can be direct or through strategy (Jackson et al., 2014; Khatri, 2000; Schuler \& Jackson, 1987).

Human Resource function deals with recruitment \& selection, orientation, training \& 
development, compensation, appraisal and career management of staff in the organization (Barney et al., 2001; De Kok et.al, 2006; Dessler, 2015; Snell \& Bohlander, 2013). Resources of human capital include the training, experience, judgement, intelligence, relationships, and insights of staff in a business (Barney 1991; Ployhart \& Moliterno, 2011). They are the most important type of capital while other types are of lesser importance (Greene \& Brown, 1997). Thus:

$\mathrm{H}_{2}$ : The human resources have significant positive impact on the growth of higher education institution.

\subsection{Operational Resources}

According to Ward et al. (1995, p. 6-7), there are four dimensions in operations strategy; the familiar competitive priorities of low cost, quality, flexibility, and delivery performance. O'Regan \& Ghobadian (2004) considered the followings as production capabilities of the small firm: distribute products broadly, deliver a broad range of products, respond to fluctuates in volume, make rapid design changes, provide after sales service, deliver products quickly, provide high performance products, deliver products on time and offer consistent quality. Acar (1993) analyzed the effects of production competencies that are site and building quality, engineering and design, technology, quality assurance, purchasing, repair and maintenance and inventory management on performance among small firms. In general, regardless of the firm size production flexibility, production quality, production cost, delivery and purchasing are the components of production capabilities (Birley \& Westhead, 1990; White, 1996).

Manufacturing flexibility deals with the ability to react to environmental changes with less time and cost (Upton, 1994). Flexibility dimension focuses on shortening the new product introduction cycle, reducing manufacturing and procurement lead-time, and reducing the time required to change products in the manufacturing process (Ward et al., 1995). In this paper, we are concerned with the new product flexibility which refers to the ability to develop and introduce new products quickly and successfully to the market (Chang et al., 2003).

Some researchers argued that flexibility affects business performance in a positive way (Oke, 2013; Patel et al., 2012). In these studies, the authors found a positive effect of product mix and new product flexibility on sales growth and net profit rate, and they also reported that firms that offered different products were able to expand their market share.

Low cost variable is concerned with reducing production cost (unit \& material costs), reducing inventory level, increasing equipment and capacity utilization for low cost production (Chaganti \& Chaganti, 1983; Ward et al., 1995).

Ward et al. (1995, p. 9) measure a manufacturing quality variable by degree of emphasis on activities to reduce defect rates, improve vendor quality, improve product performance and reliability, or activities related to achieving an international quality standard, ISO 9000 (The university lecturers delivers good quality programs/lectures). 
Purchasing comprises the ability of the organization to find suppliers and have good relations with suppliers (Brush, 2001). In purchasing capability of the firm, the quantity and quality of the suppliers are considered. The impact of organization on the prices of the suppliers is also important for the firm. In addition, relationships between the firm and suppliers are essential components of purchasing capability (Acar, 1993). Therefore, we formulated following hypothesis:

$H_{3}$ : The operational resources have significant positive impact on the growth of higher education institution.

\subsection{Marketing Resources}

When considering the marketing resources, market research, pricing and promotion need to be taken into account. Market Research variable is concerned with conducting research on the needs and desires of current and potential customers on regular basis (Barkham et al., 1996; Siu et al., 2004). Market research involves planning, collecting, and evaluating customer related information when making decisions (Aaker et al., 2004; Javalgi et al. 2006). It is very important in the sense that market research generates the data for market orientation development and implementation in which it can improve CRM (Customer Relationship Management), it has become more important with increasing globalization as the organizations needs to better utilize approaches to be aware of different customer segments worldwide (Javalgi et al., 2006). Successful companies use marketing research in their planning activities more effectively (Schlegelmilch et al., 1985). Self-generated market research impacts on company performance (Brooksbank et al., 1992; Siu et al., 2004).

Price forms the foundation of competitive advantage, is an element of marketing strategy, and pricing strategy has a strong impact on the retailer's ability to create the desired rate of return on net worth and ability to attract to target customers effectively (Radder, 1996). According to O'Regan et al. (2006), price is an important competitive factor for high growth businesses.

Promotion is an important capability for many firms (Vorhies \& Harker, 2000), it includes advertising, sales promotion and personnel selling activities for the business to communicate with the market and sell its products. According to Acar (1993), advertising and promotion includes the type, mix, and cost-effectiveness of advertising and promotion activities. An implicit marketing firm adopts various several proactive promotion methods such as determining its price according to the market, and what the competitors charge, and stay in close contact with customers to make sure that its product/ service is satisfying customer, and encourage repeat business through after-sales (Carson \& Cromie, 1990). Furthermore, it is argued that the development of an organizational website is one of the most valuable elements of e-commerce that businesses can implement as part of their promotional activities (Hormozi et al., 1998; O’Regan et al., 2006). Thus, we expect:

$H_{4}$ : The marketing resources have significant positive impact on the growth of higher education institution. 


\subsection{Financial Resources}

From a resource-based perspective, not all financial resources provide sustainable competitive advantage because most of the financial resources can be easily obtained from the external environment and can easily be imitated (Lee et al., 2001). However, financial resources are still extremely important for survival (Barkham et al., 1996; Storey, 1994).

Among financial capabilities of the firm, the most common point for consideration is the search and use of external financing (Barkham et al. 1996; Hennessy \& Whited, 2007). Firms that search and use external sources of finance is expected to grow more and faster (Birley \& Westhead, 1990). In order to grow, the firm has to invest. In a firm, investment funds come from two sources; internal sources and external agencies. Internally raised capital is limited and profit rising within the existing organization will take time to accumulate. Thus, the management of the firm can miss a good opportunity in the market. On the other hand, debt or equity can be a source of fund for the firm, but most of the firm owner/managers are reluctant to use such external financial instruments to finance growth (Barkham et al., 1996; Storey, 1994). Financial resources should be evaluated through considering internal sources of finance (Abor, 2005) and external sources of finance (Myers \& Majluf, 1984; Nishihara \& Shibata, 2013).

$H_{5}$ : The financial resources have significant positive impact on the growth of higher education institution.

\subsection{Research \& Development Resources}

Research and development (henceforth $\mathrm{R} \& \mathrm{D}$ ) is believed to be the most important determinant of innovation (Caloghirou et al., 2004). R\&D has the dimensions of improving and/or developing products and production methods. R\&D capabilities are important for the firms because they enable the firm to create innovative products and compete in the market (Siegel, et al., 1993). R\&D capabilities help the firm to create unique value to customer (Barringer et al., 2005). When describing R\&D intensive organizations, the concepts such as "high tech", "R\&D intensive" and "innovative" are interchangeably used, and that R\&D intensity refers to the extent to which financial and human resources are dedicated to $R \& D$ (Milkovich et al., 1991).

Technological competence is a dimension of $R \& D$ which is extremely important for organizations in competitive environments. Companies that are successful are more likely to modify their production technology and product mix regularly in response to the development in the industry and changing customer needs, and these type of companies are better at drawing extra financial resources (Steiner \& Solam, 1988).

According to other authors $R \& D$ intensive organizations carry the following attributes such as emphasizing inventions and innovations in their business strategies, and using certain percentage of their financial resources to R\&D (Balkin \& Gomez- Mejia, 1987; Kleingartner \& Anderson, 1987; Milkovich et al., 1991). Acs and Audretsch (1988) consider R\&D 
expenditures contribute to the innovation process.

Technological capabilities can easily provide sustainable advantage to a firm because they are mostly protected by patents which make them rare, valuable and difficult to imitate (Lee et al., 2001). Technology is an important capability for the small organizations. Utilization of new and advanced technology is considered as a vital contributor to small firm growth (Siegel et al., 1993). Being open to new technologies is proposed to provide superior performance for small firms. This impact on performance can be direct or through strategy (Gibbons \& O’Connor, 2003). Therefore:

$H_{6}:$ The research \& development resources have significant positive impact on the growth of higher education institution.

\subsection{Organizational Resources}

Organizational resources refer to the resources that are attributes of the organization itself, that is, the collections of individuals associated with a firm (Barney \& Arikan, 2002). Organizational resources are mainly internal information-based resources (Itami, 1987). When studying the organizational resources, the entrepreneurial culture and the structure of the organization needs to be taken into account.

Entrepreneurial Culture is defined as the extent to which the employees are encouraged to take risks, search for opportunities and learn from their mistakes (Brown et al., 2001; McGrath \& MacMillan, 2000). Similarly, Fayolle et al. (2010, p. 713) refers to Drucker's (1985) definition of entrepreneurial "as a climate that encourages idea generation, experimentation and creativity, and these factors are the main elements in opportunity recognition dynamics" (Drucker, 1985). An organization that follows an entrepreneurial culture encourages ideas, experimentation and creativity from organizational members in which new ideas are valued and sought out and an opportunity for innovation arises (Brown et al., 2001; Ireland et al., 2003; Covin \& Slevin, 2002). Firms with an entrepreneurial culture tend to be more profitable (Barney, 1986; Kor \& Mahoney, 2004).

Structure refers to the extent to which the structure is organic; flat, with multiple informal networks (Brown et al., 2001). This type of an organization is designed to be flexible, an environment is created for employees to create and pursue opportunity, and collaboration of employees to share knowledge is encouraged (Brown et al., 2001). In an organic knowledge based structure, multi-talented individuals perform different type of tasks, and in the flat organization, team-based activities are common and horizontal collaboration is encouraged with less rules (Ramezan, 2011).

$H_{7}$ : The organizational resources have significant positive impact on the growth of higher education institution.

In line with the arguments outlined above, our theoretical model is developed as shown on Figure 1. 


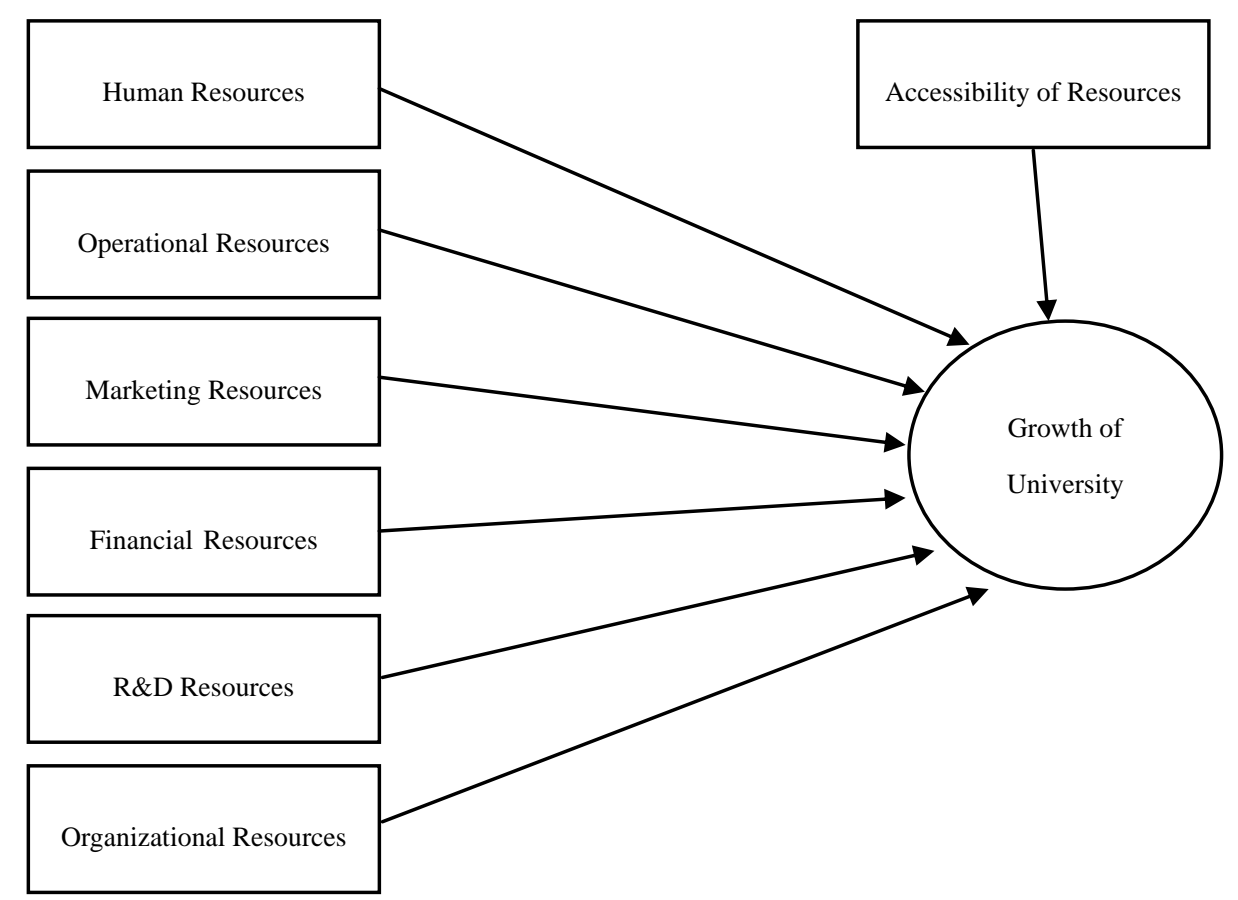

Figure 1. Theoretical model of the study

\section{Methodology}

We conducted a quantitative research design and adopted explanatory research by using a questionnaire survey to collect data and test the hypotheses.

\subsection{Operationalization of the Variables}

In Table 1, the dimensions of resources used in this study and their definitions are given. The sources of these dimensions are also provided.

Table 1. Variables of the study

\begin{tabular}{lll}
\hline \multicolumn{1}{c}{ Variable } & \multicolumn{1}{c}{ Operational Definition } & Source \\
\hline Independent Variables & & \\
\hline Accessibility of Resources & & Barkham et al. (1996) \\
\hline Access to finance & Having access to internal or external capital. & \\
Accessibility of human & The presence of supply of labor in the market in & Kok et al. (2003) \\
resources & terms of cost and quality. & Chandler \& Hanks \\
Accessibility of & The presence of raw materials in the market in & (1994) \\
physical resources & terms of cost and quality. & Chandler \& Hanks \\
Accessibility of & Having access to marketing, finance, \\
organizational & management, legal issues, and technical & (1994) \\
resources & knowledge.
\end{tabular}


Accessibility of

technological

The availability of machinery or up-to-date physical

Chandler \& Hanks facilities in terms of costs and quality.

(1994)

resources

\section{Human Resources}

Recruitment

Selection

Orientation

Training

Compensation

Appraisal

Career management

Operational Resources

\begin{tabular}{|c|c|c|}
\hline $\begin{array}{l}\text { Accessibility of } \\
\text { technological } \\
\text { resources }\end{array}$ & $\begin{array}{l}\text { The availability of machinery or up-to-date physical } \\
\text { facilities in terms of costs and quality. }\end{array}$ & $\begin{array}{l}\text { Chandler \& Hanks } \\
\text { (1994) }\end{array}$ \\
\hline \multicolumn{3}{|l|}{ Human Resources } \\
\hline Recruitment & Use of several sources to attract employees. & Kok et al. (2003) \\
\hline Selection & $\begin{array}{l}\text { Use of job analysis information, different } \\
\text { selection techniques and having selection } \\
\text { criteria. }\end{array}$ & Kok et al. (2003) \\
\hline Orientation & $\begin{array}{l}\text { Whether or not the orientation is provided by } \\
\text { coworkers or the employer. }\end{array}$ & $\begin{array}{l}\text { Cardon \& Stevens } \\
(2004)\end{array}$ \\
\hline Training & $\begin{array}{l}\text { Types and content of training provided to } \\
\text { employees. }\end{array}$ & $\begin{array}{l}\text { Cardon \& } \\
\text { Stevens (2004) }\end{array}$ \\
\hline Compensation & $\begin{array}{l}\text { Offering competitive wage, incentives and } \\
\text { performance related pay to employees. }\end{array}$ & Kok et al. (2003) \\
\hline Appraisal & $\begin{array}{l}\text { Conducts formalized appraisal, communicates } \\
\text { evaluation criteria and provides feedback. }\end{array}$ & $\begin{array}{l}\text { Kok et al. } \\
(2003)\end{array}$ \\
\hline Career management & $\begin{array}{l}\text { Ability to maintain the workforce and provide } \\
\text { career opportunities in the future. }\end{array}$ & Kickul (2001) \\
\hline \multicolumn{3}{|l|}{ Operational Resources } \\
\hline Flexibility & The ability to vary the mix of products. & Chang et al. (2003) \\
\hline Low cost & Reducing production costs (unit \& material costs) & Ward et al. (1995) \\
\hline Quality & $\begin{array}{l}\text { The ability to improve product performance } \\
\text { and reliability. }\end{array}$ & $\begin{array}{l}\text { O'Regan et al. } \\
\text { (2006); } \\
\text { Siu et al.(2004), Ward } \\
\text { et al. (1995) }\end{array}$ \\
\hline Purchasing & $\begin{array}{l}\text { The ability to find suppliers and have good } \\
\text { relations with suppliers. }\end{array}$ & Brush (2001) \\
\hline \multicolumn{3}{|l|}{ Marketing Resources } \\
\hline $\begin{array}{l}\text { Importance of } \\
\text { marketing }\end{array}$ & Overall company approach to marketing. & Siu et al. (2004) \\
\hline Pricing & $\begin{array}{l}\text { Using competitive pricing to achieve strategic } \\
\text { objectives. }\end{array}$ & $\begin{array}{l}\text { O’Regan et al. } \\
(2006)\end{array}$ \\
\hline Promotion & $\begin{array}{l}\text { Activities that are used by the firm to communicate } \\
\text { with the market and sell the product }\end{array}$ & $\begin{array}{l}\text { O’Regan et al. } \\
(2006)\end{array}$ \\
\hline Market research & $\begin{array}{l}\text { Conducting research on needs and desires of current } \\
\text { and potential customers on regular basis. }\end{array}$ & Siu et al. (2004) \\
\hline \multicolumn{3}{|l|}{ Financial Resources } \\
\hline Internal sources of finance & The strength of internal financial situation. & $\begin{array}{l}\text { Barkham et al. } \\
\text { (1996) }\end{array}$ \\
\hline External financing & Search and use of external finance. & $\begin{array}{l}\text { Barkham et al. } \\
\text { (1996) }\end{array}$ \\
\hline
\end{tabular}

Kok et al. (2003)

Kok et al. (2003)

Cardon \& Stevens

Cardon \&

Stevens (2004)

Kok et al. (2003)

Kok et al.

(2003)

Kickul (2001)

Ability to maintain the workforce and provide career opportunities in the future. performance related pay to employees.

Conducts formalized appraisal, communicates evaluation criteria and provides feedback. employees. coworkers or the employer. employees

Offering competitive wage, incentives and 
R\&D Resources

Technological competence Development and use of innovative technology.

Wheelen \&

Hunger (2000)

Wheelen \&

R\&D intensity

The organizations spending on R\&D.

Hunger (2000)

R\&D capability

The quality and quantity of R\&D personnel.

Atuahene-Gima

(1993)

\begin{tabular}{lll}
\hline Organizational Resources & & \\
\hline Entrepreneurial Culture & $\begin{array}{l}\text { The extent to which the employees are encouraged to } \\
\text { take risks, search for opportunities and learn from } \\
\text { their mistakes. } \\
\text { The extent to which the structure is organic; flat, with } \\
\text { multiple informal networks. }\end{array}$ & $\begin{array}{l}\text { Brown et al. } \\
(2001)\end{array}$ \\
Structure & $\begin{array}{l}\text { Brown et al. } \\
\text { Dependent Variable }\end{array}$ & \% increase in number of students enrolled
\end{tabular}

\subsection{Sampling and Data Collection}

Data for this study were collected from a sample of 5 local universities operating in higher education sector of North Cyprus. These five universities represent $45 \%$ of total number of local universities which are currently operating in North Cyprus. The rationale for choosing these five universities is their minimum 10 years of history in higher education sector. A structured questionnaire was developed in order to investigate the factors related to growth of university. Data was collected through personal face to face interviews. The questionnaire was conducted to both academic and administrative staff of universities. In total, the questionnaire was applied to 343 persons in these five universities; consists of 172 administrative and 171 academic staff. The characteristics of the sample are provided on Table 2.

Table 2. Descriptive Statistics of Sample

\begin{tabular}{lrr}
\hline & Frequency & Percent \\
\hline University & & \\
\hline 1 & 68 & 19.8 \\
2 & 70 & 20.4 \\
3 & 69 & 20.1 \\
4 & 70 & 20.4 \\
5 & 66 & 19.2 \\
Total & $\mathbf{3 4 3}$ & $\mathbf{1 0 0 . 0}$ \\
\hline Position of Person & & \\
\hline Administrative & 172 & 50.9 \\
Academic & 171 & 50.1 \\
Total & $\mathbf{3 4 3}$ & $\mathbf{1 0 0 . 0}$ \\
\hline
\end{tabular}




\begin{tabular}{lrr}
\hline Seniority of Person & & \\
\hline Less than 1 year & 54 & 15.7 \\
1-3 years & 104 & 30.3 \\
4-6 years & 85 & 24.8 \\
7-9 years & 41 & 12.0 \\
More than 10 years & 59 & 17.2 \\
Total & $\mathbf{3 4 3}$ & $\mathbf{1 0 0 . 0}$ \\
\hline \multicolumn{4}{l}{ Years of University in Sector } & \\
15-19 years & 69 & 20.1 \\
More than 20 years & 274 & 79.9 \\
Total & $\mathbf{3 4 3}$ & $\mathbf{1 0 0 . 0}$ \\
\hline
\end{tabular}

\subsection{Data Analysis}

The collected data was initially analyzed by reliability and factor analysis. The internal consistency of a scale is measured by the Cronbach Alpha reliability analysis. Factor analysis is conducted in order to eliminate the items with low reliabilities. The test results for both reliability and factor analysis are given on Table 3.

Table 3. Reliability and Validity Test of the study

\begin{tabular}{clcc}
\hline $\begin{array}{c}\text { Questionnaire } \\
\text { Items }\end{array}$ & \multicolumn{1}{c}{ Measures } & $\begin{array}{c}\text { Factor } \\
\text { Loadings }\end{array}$ & $\begin{array}{c}\text { Cronbach's } \\
\text { Alpha }\end{array}$ \\
\hline & Accessibility of Resources & $\mathbf{0 . 8 4 9}$ \\
\hline B1 & Access to Finance & 0.749 & \\
B2 & Access to Human Resources & 0.800 & \\
B3 & Access to Physical Resources & 0.826 & \\
B4 & Access to Organizational Resources & 0.811 & \\
B5 & Access to Technological Resources & 0.765 & \\
\hline & Operational Resources & & \\
\hline F1 & Flexibility & 0.834 & \\
F2 & Low cost & 0.698 & \\
F3 & Quality & 0.845 & \\
F4 & Purchasing & 0.830 & \\
\hline & Marketing Resources & & \\
\hline F5 & Market Research & 0.774 & \\
F6 & Pricing & 0.592 & \\
F7 & Importance of Marketing & 0.835 & \\
F8 & Promotion & 0.801 & \\
\hline F9 & Financial Resources & 0.845 & \\
\hline F10 & Internal Finance & 0.893 & \\
\hline F11 & External Finance & & \\
\hline & R\&D Resources & & \\
\hline & Technological Competence & & \\
\hline & & & \\
\hline
\end{tabular}




\begin{tabular}{llll} 
F12 & R\&D Intensity & 0.906 & \\
F13 & R\&D Capability & 0.890 & \\
\hline & Human Resources & & $\mathbf{0 . 8 1 3}$ \\
\hline F14 & Recruitment & 0.595 & \\
F15 & Selection & 0.685 & \\
F16 & Training & 0.834 & \\
F17 & Orientation & 0.760 & \\
F18 & Compensation & 0.677 & \\
F19 & Performance Appraisal & 0.759 & \\
F20 & Career Management & 0.804 & \\
\hline & Organizational Resources & & $\mathbf{0 . 7 4 5}$ \\
\hline F21 & Entrepreneurial Culture & 0.803 & \\
F22 & Organic Structure & 0.803 &
\end{tabular}

\section{Findings}

Besides from the analyses of proposed research model, the main aim of this research is to find the determinants of growth in higher education institutions. Therefore, multiple regression analyses are conducted for each independent variable and growth as the dependent variable. A summary of findings of direct effects of independent variables on university growth can be found on Table 4.

Table 4. Multiple Regression Coefficients of the study

\begin{tabular}{lccccc}
\hline \multirow{2}{*}{ Model } & \multicolumn{2}{c}{$\begin{array}{c}\text { Unstandardized } \\
\text { Coefficients }\end{array}$} & $\begin{array}{c}\text { Standardized } \\
\text { Coefficient }\end{array}$ & \multirow{2}{*}{$\mathbf{t}$} & \multirow{2}{*}{ Sig. } \\
\cline { 2 - 5 } & $\mathbf{B}$ & Std. Error & Beta & & \\
\hline Accessibility of Resources & $\mathbf{1 . 0 5 9}$ & $\mathbf{. 3 9 9}$ & $\mathbf{. 1 7 2}$ & $\mathbf{2 . 6 5 6}$ & $\mathbf{. 0 0 8}$ \\
\hline Operational Resources & .221 & .500 & .036 & .442 & .659 \\
\hline Marketing Resources & $\mathbf{2 . 9 1 4}$ & $\mathbf{. 4 8 0}$ & $\mathbf{. 4 4 8}$ & $\mathbf{6 . 0 7 4}$ & $\mathbf{. 0 0 0}$ \\
\hline Financial Resources & .219 & .385 & .038 & .569 & .570 \\
\hline R\&D Resources & $\mathbf{1 . 0 7 2}$ & $\mathbf{. 4 2 7}$ & $\mathbf{. 1 9 5}$ & $\mathbf{2 . 5 1 1}$ & $\mathbf{. 0 1 3}$ \\
\hline Human Resources & $\mathbf{1 . 9 8 6}$ & $\mathbf{. 4 9 0}$ & $\mathbf{. 2 8 8}$ & $\mathbf{4 . 0 5 2}$ & $\mathbf{. 0 0 0}$ \\
\hline Organizational Resources & $\mathbf{. 9 0 8}$ & $\mathbf{. 3 2 7}$ & $\mathbf{. 1 5 1}$ & $\mathbf{2 . 7 8 0}$ & $\mathbf{. 0 0 6}$ \\
\hline $\mathbf{R}^{2}$ & $\mathbf{. 2 0 3}$ & & & & \\
F & $\mathbf{1 2 . 1 7 2}$ & & & & \\
Sig. & $\mathbf{. 0 0 0}$ & & & & \\
\hline
\end{tabular}

When regression analyses were conducted for all of the resources scale, in order to find out their impact on the growth only five significant results were obtained $\left(\mathrm{R}^{2}=0.203, \mathrm{~F}=12.172\right.$, $\mathrm{p}=0.000$ ). These five results in fact explain $20 \%$ of growth. Marketing resources had the highest and positive contribution to growth of universities with $\beta=0.448$. Human resources had a slightly lower positive contribution $(\beta=0.288)$. R\&D resources $(\beta=0.195)$ and accessibility of resources $(\beta=0.172)$ had lower and positive contribution to growth of 
universities. Organizational resources had the lowest positive contribution to growth $(\beta=0.151)$. Both operational and financial resources had not shown any contribution to the growth of universities in North Cyprus. Therefore, hypotheses 1, 2, 4, 6 and 7 are accepted, but hypotheses 3 and 5 are rejected. A summary of findings is also illustrated on Figure 2.

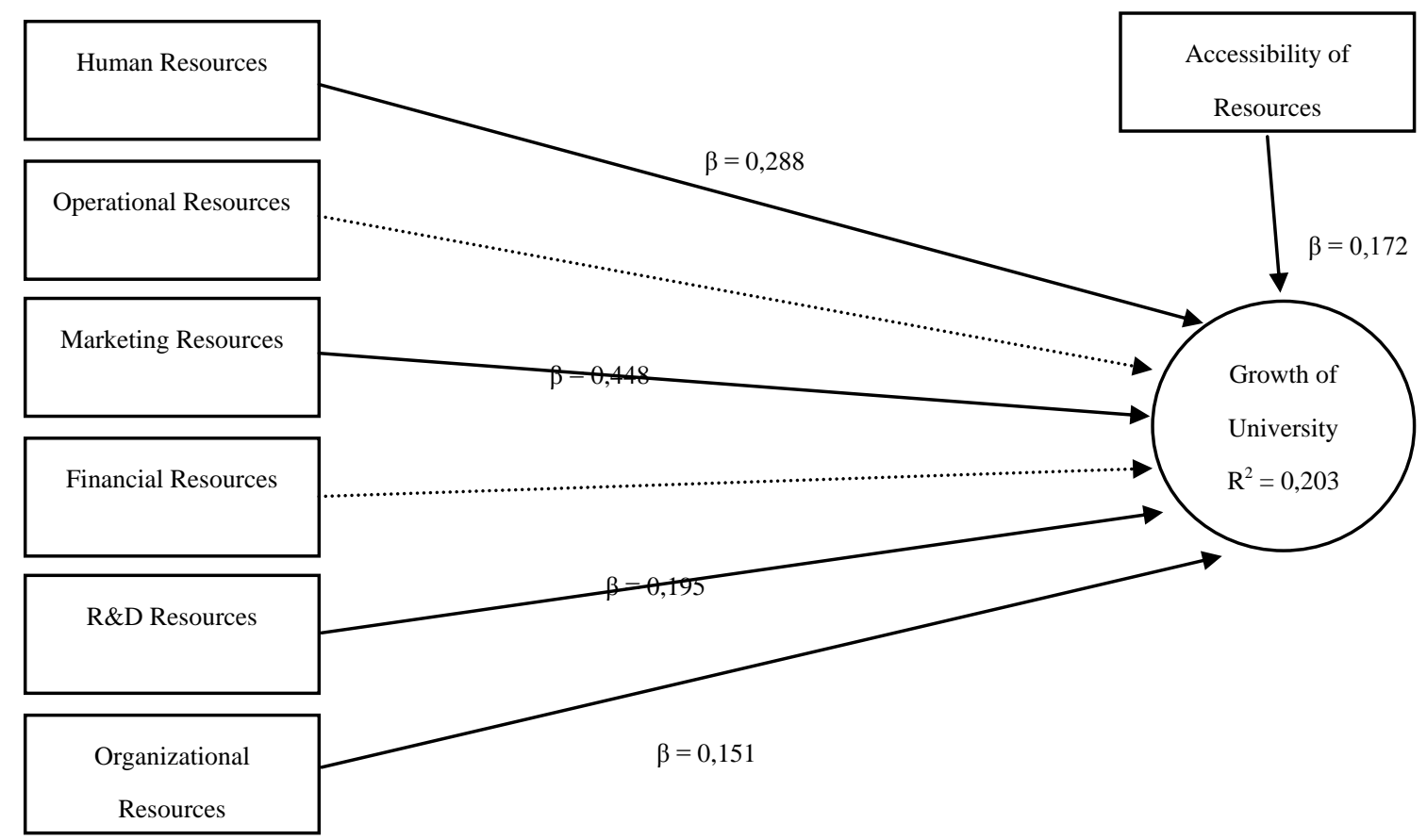

Figure 2. Findings of the study

\section{Discussions}

The impact of firm resources and capabilities on firm performance has been intensively studied in marketing and management (Krasnikov \& Jayachandran 2008; Newbert 2007). Resource theory researchers have demonstrated that firm resources and capabilities exert influence on a firm's intermediate and ultimate performance. In general, when a firm has a superior resource base, it will be more likely to outperform its competitors because those resources enable the firm to gain better advantages in technological, marketing and operational activities, which in turn bring competitive advantages. Similarly, when a firm has built better capabilities (the ability to deploy firm resources), it has a stronger potential to optimize its activities for serving its stakeholders, including customers and shareholders (Dutta et al., 1999; Makadok, 2001; Vorhies et al., 2009).

The results of our model prove that selected resources are important antecedents of university growth. Among all the resources, marketing has the highest contribution to the growth. The marketing capability will significantly interact with other functional capabilities and therefore help realize high performance. For example, a university's innovative activities will gain the most from marketing capability in their contribution to overall performance. This view is supported by Krasnikov \& Jayachandran (2008) in a meta-analysis in which they compare the 
impacts of marketing, $R \& D$ and operations capabilities and find marketing capability is more important in determining firm performance. These findings help explain marketing capability's superior importance in interacting with other resources and capabilities (Dutta et al., 1999). Krasnikov \& Jayachandran (2008) suggest that marketing capability, compared to other firm strategic capabilities, is more difficult for rivals to imitate because it is more embedded in firm processes. The underlying reason is that marketing capability is based on knowledge about the market and a firm's experience in dealing with customer needs and competitor actions (Day, 1994). As a result, marketing capability integrates a firm's overall strategies, image and reputation. Therefore, marketing capability is especially important because it represents one of a firm's most critical drivers in gaining competitive advantage.

In addition to that, the success of a university depends on the quality of its human resources and the acceptance that human resource management is the heart of any successful educational administration. Human resource has a strategic importance on the success of a university. It is impossible to make maximal use of material resources if the university lacks qualified, enthusiastic employees who have the stamina to perform their jobs. The human resource transforms material resources into goods and services, and the quality of this transformation depends on a combination of knowledge, skill and attitude. By the growing understanding about human who is the most important capital of an organization due to her/his ability to convert existing sources to products and services, Human Resource Management has started to gain importance. Fundamentally, the Human Resource Management aims to improve the contribution of the strategic partner 'human' to the organization by each of its functions called Human Resource Functions.

Our research has also confirmed that university's R\&D investments or capabilities improve its growth. The fundamental reason is that a university committed to R\&D engages in building technological ability and facilitating innovations, designing superior programs, and improving efficiency for the whole operation process. Therefore, $R \& D$ is a value-creation driver which strongly boosts university's performance. Some other studies show that R\&D, as a foundation of firm operations, not only improves firm performance, but also augments a firm's market value and superior stock returns on financial markets (Mizik \& Jacobson 2003). Furthermore, arguing that $R \& D$ is capable of creating intangible assets for a firm as well as assuring its investors. McAlister et al. (2007) find that R\&D is has the ability to consistently reduce a firm's systematic risk, insulating the firm against the volatility of market downturns.

Every university has its own unique culture. However, an organization's particular type of culture had a significant influence on its short- and long-range performance. Entrepreneurial Orientation (EO) has emerged as an important construct used to describe the entrepreneurial posture or entrepreneurial activity level within organizations. Often conceptualized as an attribute of the firm, EO is in fact a psychological measure of individual EO (Krauss et al., 2005). It is associated with a propensity for managers to act innovatively, proactively, and undertake projects with greater risk. The accelerating rate of technology change, modern globalization, and increased competition lead researchers to anticipate that higher levels of 
EO will lead managers to better recognize and exploit emerging opportunities to create strategic advantage and ultimately achieve greater performance (Pett \& Wolff, 2007).

Fundamentally, EO relates to a set of attitudes and beliefs about a manager's own ability and effective management styles. These attitudes and beliefs are manifest in the form of strategies, decisions, communications, and actions. Managers with similar EO levels may differ significantly in the expression and manifestation of their respective EO. Performance may be related to the tendency to act entrepreneurially, but may be more strongly related to the ability to successfully execute the entrepreneurial strategies required to recognize and profitably exploit opportunity.

Another valuable organizational resource is the organizational structure of the university. However, the organizational structure and performance relationship in educational institutions has received inadequate consideration from the researchers in the field. After the establishment of a firm, some employees have to be hired to perform the tasks. This leads to determination of responsibilities among employees and development of coordination mechanisms which are in fact the formation process of the firm structure. The organizational structure primarily focuses on two dimensions: the first dimension is the work division which is the distribution of work tasks and activities and the second dimension is the coordination mechanisms of the firm that is the level of standardization and formalization (Meijaard et al., 2005). The structure of an organization is important for the development and implementation of strategy, division of work and labor, coordination and integration of functions, and flow of information (Chrisman, 1999). It also influences allocation of power and responsibility, formalization and organizational complexity (Miller, 1987).

Organizational structure and its effect on performance are mainly analyzed in organic versus mechanistic structures (Covin \& Slevin, 1990). Siegel et al. (1993) found that lean structures were more suitable for high growth firms. Structure of an organization is argued to be a determinant on the strategy of the firm. Mechanistic structures inhibit innovative strategies whereas organic structures enable innovation (Romano, 1990).

\section{Conclusion}

A model of growth drawing on the resource-based perspective of the firm was developed in this study and was tested empirically with North Cyprus universities' data. The results indicate that the theoretical model matches well with empirical data and that the analytical method advanced here could serve as a meaningful way to develop a more rigorous theoretical model that can be validated across a number of country samples. Marketing, Human, R\&D, Organizational resources and accessibility of these resources have been shown to influence positively university growth.

The research on the growth of universities should pay more attention to the resources and capabilities of the universities. Our knowledge about the resources and capabilities of the universities is still limited. In this study, some findings also suggest that resources beneficial to commercial firms do not have impact on the educational institutions. Hence, this study also 
proved that commercial firms and educational institutions are different. They have their own dynamics. In order to find these dynamics, the researchers in the field have to reveal the factors that are specific to educational institution concept.

\section{References}

Aaker, D. A., Kumar, V., \& Day, G. S. (2004). Marketing Research. (8th ed.). New York: John Wiley \& Sons.

Abor, J. (2005). The effect of capital structure on profitability: an empirical analysis of listed firms in Ghana. The Journal of Risk Finance, 6(5), 438-445. http://dx.doi.org/10.1108/15265940510633505

Acar, A. (1993). The Impact of Key Internal Factors on Firm Performance: An Empirical Study of Small Turkish Firms. Journal of Small Business Management, 31(4), 86-92.

Acs, Z., \& Audretsch, D. (1988). Innovation in large and small firms: An empirical analysis. American Economic Review, 78(4), 678-690. http://dx.doi.org/10.1016/0165-1765(87)90211-4

Atuahene-Gima, K. (1993). Determinants of inward technology licensing intentions: An empirical analysis of Australian engineering firms. Journal of Product Innovation Management, 10(3), 230-240. http://dx.doi.org/10.1111/1540-5885.1030230

Balkin, D. B., \& Gomez-Mejia, L. R. (1987). Toward a contingent theory of compensation strategy. Strategic Management Journal, 8, 169-182.

Barkham, R, Gudgin, G., Hart, M., \& Hanvey, E. (1996). The Determinants of Small Firm Growth. UK: Gateshead, Tyne and Wear, Athenaeum Press.

Barney, J. (1991). Firm resources and sustained competitive advantage. Journal of Management, 17(1), 99-120. http://dx.doi.org/10.1177/014920639101700108

Barney, J. B., Wright, M., \& Ketchen, D. J. (2001). The resource based view of the firm: Ten years after 1991. Journal of Management, 27(6), 625-43. http://dx.doi.org/10.1177/014920630102700601

Barringer, B. R, Jones, F. F., \& Neubaum, D. O. (2005). A Quantitative Content Analysis of the Characteristics of Rapid-Growth Firms and Their Founders. Journal of Business Venturing, 20(5), 663-687. http://dx.doi.org/10.1016/j.jbusvent.2004.03.004

Baum, R. J., Locke, E. A., \& Smith, K. G. (2001). A Multidimensional Model of Venture Growth. Academy of Management Journal, 44(2), 292-302.

Becker, B. E., \& Huselid, M. A. (1998). High performance work systems and firm performance: A synthesis of research and managerial implications. Research in Personnel and Human Resources Management, 16, 53-102.

Bhide, A. (2000). The Origins and Evolution of New Businesses. Boston: Harvard Business 
School Press.

Birley, S., \& Westhead, P. (1990). Growth and Performance Contrasts between "Types" of Small Firms. Strategic Management Journal, 11(7), 535-557. http://dx.doi.org/10.1002/smj.4250110705

Bowen, D. E., \& Ostroff, C. (2004). Understanding HRM firm performance linkages: The role of the "strength" of the HRM system. Academy of Management Review, 29(2), 203-221. http://dx.doi.org/10.2307/20159029

Brooksbank, R., Kirby, D. A., \& Wright, G. (1992). Marketing and company performance: An examination of medium sized manufacturing firms in Britain. Small Business Economics. 4(3), 221-236. http://dx.doi.org/10.1007/BF00389477

Brown, T. E. (1996). Resource Orientation, Entrepreneurial Orientation and Growth: How the Perception of Resource Availability Affects Small Firm Growth. Unpublished Doctoral Dissertation. Rutgers University, Newark, NJ.

Brown, T. E., Davidsson, P., \& Wiklund, J. (2001). An Operationalization of Stevenson's Conceptualization of Entrepreneurship as Opportunity Based Behavior. Strategic Management Journal, 22(10), 953-968.

Brush, G. (2001). The Effects of Supplier Size and Location on the Development of Small High-Technology Manufacturer - Supplier Relationships: An Empirical Investigation with Performance Implications. ANZMAC Conference (1st-5th December), Massey University, New Zealand.

Bruton, G. D., \& Rubanik, Y. (2002). Resources of the Firm, Russian High-Technology Startups, and Firm Growth. Journal of Business Venturing, 17(6), 553-576. http://dx.doi.org/10.1016/S0883-9026(01)00079-9

Buller, P. F., \& McEvoy, G. M. (2012). Strategy, human resource management and performance: Sharpening line of sight. Human Resource Management Review, 22(1), 43-56. http://dx.doi.org/10.1016/j.hrmr.2011.11.002

Caloghirou, Y., Kastelli, I., \& Tsakanikas, A. (2004). Internal capabilities and external knowledge sources: Complements or substitutes for innovative performance. Technovation, 24(1), 29-39. http://dx.doi.org/10.1016/S0166-4972(02)00051-2

Cardon, M. S., \& Stevens, C. E. (2004). Managing human resources in small organizations: What do we know? Human Resource Management Review, 14(3), 295-323. http://dx.doi.org/10.1016/j.hrmr.2004.06.001

Carmeli, A., \& Tishler, A. (2004a). Resources, capabilities, and the performance of industrial firms: A multivariate analysis. Managerial and Decision Economics, 25(6-7), 299-315. http://dx.doi.org/10.1002/mde.1192

Carmeli, A., \& Tishler, A. (2004b). The relationships between intangible organizational 
elements and organizational performance. Strategic Management Journal, 25(13), 1257-1278. http://dx.doi.org/10.1002/smj.428

Carson, D., \& Cromie, S. (1990). Marketing planning in small enterprises: a model and some empirical evidence. Journal of Consumer Marketing, 7(3), 5-18. http://dx.doi.org/10.1108/EUM0000000002578

Castrogiovanni, G. (1991). Environmental munificence: A theoretical assessment. Academy of Management Review, 16(3), 542-565. http://dx.doi.org/10.5465/AMR.1991.4279475

Chan, L., Shaffer, M., \& Snape, E. (2004). In search of sustained competitive advantage: The impact of organizational culture, competitive strategy and human resource management practices on firm performance. International Journal of Human Resource Management, 15(1), 17-35. http://dx.doi.org/10.1080/0958519032000157320

Chandler, G., \& Hanks, S. (1994). Market Attractiveness, Resource-Based Capabilities, Venture Strategies and Venture Performance. Journal of Business Venturing, 9(4), 331-349. http://dx.doi.org/10.1016/0883-9026(94)90011-6

Chang, S. C., Yang, C. L., Cheng, H. C., \& Sheu, C. (2003). Manufacturing Flexibility and Business Strategy: An Empirical Study of Small and Medium Sized Firms. International Journal of Production $\quad$ Economics, $\quad 83(1), \quad$ 13-26. http://dx.doi.org/10.1016/S0925-5273(02)00263-3

Chrisman, J. J. (1999). The influence of outsider-generated knowledge resources on venture creation. Journal of Small Business Management, 37(4), 42.

Covin, J. G., \& Slevin, D. P. (1990). New Venture Strategic Posture, Structure, and Performance: An Industry Life Cycle Analysis. Journal of Business Venturing, 5(2), 123-135. http://dx.doi.org/10.1016/0883-9026(90)90004-D

Davidsson, P., \& Wiklund, J. (2000). Conceptual and empirical challenges in the study of firm growth. In D. Sexton \& H. Landström (Eds.), The Blackwell Handbook of Entrepreneurship. Oxford, MA: Blackwell. http://dx.doi.org/10.4337/9781781009949.00010

Day, G. S. (1994). The capabilities of market-driven organizations. The Journal of Marketing, 58(4), 37-52. http://dx.doi.org/10.2307/1251915

De Kok, J. M. P., Uhlaner, L. M., \& Thurik, A. R. (2006). Professional HRM Practices in Family Owned-Managed Enterprises. Journal of Small Business Management, 44(3), 441-460. http://dx.doi.org/10.1111/j.1540-627X.2006.00181.x

De Kok, J. M. P., Uhlaner, L. M., \& Thurik, R. (2003). Human resource Management with small firms: facts and explanations. ERIM Report Series ERS 2003-015, Rotterdam: Erasmus University.

Delmar, F., McKelvie, A., \& Wennberg, K. (2013). Untangling the relationships among growth, profitability and survival in new firms. Technovation, 33(8-9), 276-291. 
http://dx.doi.org/10.1016/j.technovation.2013.02.003

Deshpande, S. P., \& Golhar, D. Y. (1994). HRM practices in large and small manufacturing firms: A comparative study. Journal of Small Business Management, 32(2), 49-56.

Dessler, G. (2015). Human Resource Management. Prentice Hall: Boston.

Dhanaraj, C., \& Beamish, P. W. (2004). Effect of equity ownership on the survival of international joint ventures. Strategic Management Journal, 25(3), 295-305. http://dx.doi.org/10.1002/smj.372

Drucker, P. F. (1985). The discipline of innovation. Harvard Business Review, 63(3), 67-72. http://dx.doi.org/10.1002/lt1.40619980906

Dutta, S., Narasimhan, O., \& Rajiv, S. (1999). Success in high-technology markets: Is marketing capability critical? Marketing Science, 18(4), 547-568. http://dx.doi.org/10.1287/mksc.18.4.547

Edelman, L. F., Brush, C., \& Manolova, T. S. (2005). Co-Alignment in the Resource-Performance Relationship: Strategy as Mediator. Journal of Business Venturing, 20(3), 359-383. http://dx.doi.org/10.1016/j.jbusvent.2004.01.004

Fayolle, A., Basso, O., \& Bouchard, V. (2010). Three levels of culture and firms' entrepreneurial orientation: A research agenda. Entrepreneurship and Regional Development, 22(7-8), 707-730. http://dx.doi.org/10.1080/08985620903233952

Galende, J., \& De la Fuente, J. M. (2003). Internal factors determining a firm's innovative behavior. Research Policy, 32(5), 715-736.

Gibb, A., \& Davies, L. (1990). In pursuit of frameworks for the development of growth models of the small business. International Small Business Journal, 9(1), 15-31.

Gibbons, P. T., \& O'Connor, T. (2003). Strategic Posture, Technology Strategy and Performance among Small Firms. Journal of Enterprising Culture, 11(2), 131-147. http://dx.doi.org/10.1142/S0218495803000081

Grant, R. M. (1991). The Resource Based Theory of Competitive Advantage: Implications for Strategy Formulation. California Management Review, 33(3), 114-135. http://dx.doi.org/10.2307/41166664

Greene, P., Brush, C., \& Brown, T. (1997). Resources in small firms: an exploratory study. Journal of Small Business Strategy, 8(23), 29- 40.

Greene, P., \& Brown, T. (1997). Resource needs and the dynamic capitalism typology. Journal of Business Venturing, $\quad 12(3), \quad 161 \quad-\quad 174$. http://dx.doi.org/10.1016/S0883-9026(96)00060-2

Hart, S. L., \& Dowell, G. (2011). A natural-resource-based view of the firm: Fifteen years after. Journal of Management, 37(5), 1464-1479. http://doi.dx.org/ 
$10.1177 / 0149206310390219$

Hennessy, C. A., \& Whited, T. M. (2007). How costly is external financing? Evidence from a structural estimation. The Journal of Finance, 62(4), 1705-1745. http://dx.doi.org/10.1111/j.1540-6261.2007.01255.x

Hofer, C. W., \& Schendel, D. E. (1978). Strategy Formulation: Analysis \& Concepts. St. Paul, MN: West Publishing.

Hormozi, A. M., Harding, W. T., \& Bose, U. (1998). Is the Internet feasible and profitable for small businesses? SAM Advanced Management Journal, 63(3), 20-27.

Hornsby, J. S., \& Kuratko, D. F. (1990). Human Resource Management in Small Business: Critical Issues for the 1990s. Journal of Small Business Management, 28(3), 9-18.

Hoskisson, R. E., Hitt, M. A., Wan, W. P., \& Yiu, D. (1999). Theory and research in strategic management: swings of a pendulum. Journal of Management, 25(3), 417-456. http://dx.doi.org/10.1177/014920639902500307

Ireland, R. D., Hitt, M. A., \& Sirmon, D. G. (2003). A Model of Strategic Entrepreneurship: The Construct and its Dimensions. Journal of Management, 29(6), 963-989. http://dx.doi.org/10.1016/S0149-2063_03_00086-2

Jackson, S. E., Schuler, R. S., \& Jiang, K. (2014). An aspirational framework for strategic human resource management. The Academy of Management Annals, 8(1), 1-56. http://dx.doi.org/10.1080/19416520.2014.872335

Javalgi, R. R. G., Martin, C. L., \& Young, R. B. (2006). Marketing research, market orientation and customer relationship management: a framework and implications for service providers. Journal of Services Marketing, 20(1), 12-23. http://dx.doi.org/10.1108/08876040610646545

Katircioglu, S. T. (2010). International Tourism, Higher Education and Economic Growth: The Case of North Cyprus. The World Economy, 33(12), 1955-1972. http://dx.doi.org/10.1111/j.1467-9701.2010.01304.x

Khatri, N. (2000). Managing human resource for competitive advantage: A study of companies in Singapore. International Journal of Human Resource Management, 11(2), 336-365. http://dx.doi.org/10.1080/095851900339909

Kickul, J. (2001). Promises made, promises broken: An exploration of employee attraction and retention practices in small business. Journal of Small Business Management, 39(4), 320. http://dx.doi.org/10.1111/0447-2778.00029

Kleingartner, A., \& Anderson, K. S. (1987). Human Resource Management in High Technology Firms. $\quad$ Lexington, Mass.: Lexington Books.

Krasnikov, A., \& Jayachandran, S. (2008). The relative impact of marketing, 
research-and-development, and operations capabilities on firm performance. Journal of Marketing, 72(4), 1-11. http://dx.doi.org/10.1509/jmkg.72.4.1

Krauss, S. I., Frese, M., Friedrich, C., \& Unger, J. M. (2005). Entrepreneurial orientation: A psychological model of success among southern African small business owners. European Journal of Work and Organizational Psychology, 14(3), 315-344. http://dx.doi.org/10.1080/13594320500170227

Lee, C., Lee, K., \& Pennings, J. M. (2001). Internal Capabilities, External Networks, and Performance: A Study on Technology-Based Ventures. Strategic Management Journal, 22(6-7), 615-640. http://dx.doi.org/10.1002/smj.181

Lisboa, A., Skarmeas, D., \& Lages, C. (2011). Entrepreneurial orientation, exploitative and explorative capabilities, and performance outcomes in export markets: A resource-based approach. Industrial Marketing Management, 40(8), 1274-1284. http://dx.doi.org/10.1016/j.indmarman.2011.10.013

Lumpkin, G. T., \& Dess, G. G. (2001). Linking Two Dimensions of Entrepreneurial Orientation to Firm Performance: The Moderating Role of Environment and Industry Life Cycle. Journal of Business Venturing, 16(5), 429-451.

Lussier, R. N., \& Pfeifer, S. (2001). A crossnational prediction model for business success. Journal of Small Business Management, 39(3), 228-239. http://dx.doi.org/10.1111/0447-2778.00021

Makadok, R. (2001). Toward A Synthesis of the Resource-Based and Dynamic-Capability Views of Rent. Strategic Management Journal, 22(5), 387-401. http://dx.doi.org/10.1002/smj.158

McAlister, L., Srinivasan, R., \& Kim, M. (2007). Advertising, research and development, and systematic risk of the firm. Journal of Marketing, 71(1), 35-48. http://dx.doi.org/10.1509/jmkg.71.1.35

McWilliams, A., \& Siegel, D. S. (2011). Creating and Capturing Value: Strategic Corporate Social Responsibility, Resource-Based Theory, and Sustainable Competitive Advantage. Journal of Management, 37(5), 1480-1495. http://dx.doi.org/10.1177/0149206310385696

Meijaard, J., Brand, M. J., \& Mosselman, M. (2005). Organizational structure and performance in Dutch small firms. Small Business Economics, 25(1), 83-96. http://dx.doi.org/10.1007/s11187-005-4259-7

Milkovich, G. T., Gerhart, B., \& Hannon, J. (1991). The effects of research and development intensity on managerial compensation in large organizations. The Journal of High Technology Management Research, 2(1), 133-150. http://dx.doi.org/10.1016/1047-8310(91)90018-J

Miller, D. (1987). Strategy Making and Structure: Analysis and Implication for Performance. Academy of Management Journal, 30(1), 7-32. http://dx.doi.org/10.2307/255893 
Mishina, Y., Pollock, T. G., \& Porac, J. F. (2004). Are more resources always better for growth? Resource stickiness in market and product expansion. Strategic Management Journal, 25, 1179-1197. http://dx.doi.org/10.1002/smj.424

Mizik, N., \& Jacobson, R. (2003). Trading off between value creation and value appropriation: The financial implications of shifts in strategic emphasis. Journal of Marketing, 67(1), 63-76. http://dx.doi.org/10.1509/jmkg.67.1.63.18595

Myers, S., \& Majluf, N. (1984). Corporate financing and investment decisions when firms have information that investors do not have. Journal of Financial Economics, 13(2), 187-221. http://dx.doi.org/10.1016/0304-405X(84)90023-0

Newbert, S. L. (2007). Empirical research on the resource-based view of the firm: An assessment and suggestions for future research. Strategic Management Journal, 28(2), 121-146.

Nishihara, M., \& Shibata, T. (2013). The effects of external financing costs on investment timing and sizing decisions. Journal of Banking \& Finance, 37(4), 1160-1175. http://dx.doi.org/10.1016/j.jbankfin.2012.11.014

O'Farrell, P. N., \& Hitchens, D. M. W. N. (1988). Alternative Theories of Small-Firm Growth: A Critical Review. Environment and Planning A, 20, 1365-1383. http://dx.doi.org/10.1068/a201365

Oke, A. (2013). Linking manufacturing flexibility to innovation performance in manufacturing plants. International Journal of Production Economics, 143(2), 242-247. http://dx.doi.org/10.1016/j.ijpe.2011.09.014

O'Regan, N., \& Ghobadian, A. (2004). The importance of capabilities for strategic direction and performance. Management Decision, 292-313. http://dx.doi.org/10.1108/00251740410518525

O'Regan, N., Ghobadian, A., \& Gallear, D. (2006). In search of the drivers of high growth in manufacturing SMEs. Technovation, 30-41. http://dx.doi.org/10.1016/j.technovation.2005.05.004

Park, S., \& Bae, Z. T. (2004). New venture strategies in a developing country: Identifying a typology and examination growth patterns through case studies. Journal of Business Venturing, 19(1), 81-105. http://dx.doi.org/10.1016/S0883-9026(02)00110-6

Patel, P. C., Terjesen, S., \& Li, D. (2012). Enhancing effects of manufacturing flexibility through operational absorptive capacity and operational ambidexterity. Journal of Operations Management, 30(3), 201-220. http://dx.doi.org/10.1016/j.jom.2011.10.004

Penrose, E. (1959). The theory of growth of the firm. New York: John Wiley \& Sons. http://dx.doi.org/10.1016/S0024-6301(96)90295-2

Perry, D., \& Wiewel, W. (2005). The university as urban developer: Case studies and 
analysis. Cambridge, MA: Lincoln Land Institute.

Pett, T. L., \& Wolff, J. A. (2007). SME performance: A case for internal consistency. Journal of Small Business Strategy, 18(1), 1-16.

Ployhart, R. E., \& Moliterno, T. P. (2011). Emergence of the human capital resource: A multilevel model. Academy of Management Review, 36(1), 127-150.

Powers, J., \& McDougall, P. (2005). University start-up formation and technology licensing with firms that go public: a resource based view of academic entrepreneurship. Journal of Business Venturing, 20(3), 291-311. http://dx.doi.org/10.1016/j.jbusvent.2003.12.008

Radder, L. (1996). The Marketing Practices of Independent Fashion Retailers: Evidence from South Africa. Journal of Small Business Management, 34(1), 78-84.

Ramezan, M. (2011). Intellectual capital and organizational organic structure in knowledge society: How are these concepts related? International Journal of Information Management, 31(1), 88-95. http://dx.doi.org/10.1016/j.ijinfomgt.2010.10.004

Riding, A.L., \& Haines, G. (2001). Loan guarantees: costs of default and benefits to small firms. Journal of Business Venturing, 16(6), 595-612. http://dx.doi.org/10.1016/S0883-9026(00)00050-1

Robinson, K. C., \& McDougall, P. P. (2001). Entry barriers and new venture performance: A comparison of universal and contingency approaches. Strategic Management Journal, 22(6-7), 659-685. http://dx.doi.org/10.1002/smj.186

Romano, C. A. (1990). Identifying Factors which Influence Product Innovation. Journal of Management Studies, 27(1), 75-96.

Schlegelmilch, B. B., Boyle, K. M., \& Therivel, S. (1985). Marketing research in medium sized engineering companies in Britain and the United States - some preliminary findings. Working Paper Series No. 86/16, Edinburgh University.

Schuler, R. S., \& Jackson, S. E. (1987). Linking Competitive Strategies with Human Resource Management Practices. Academy of Management Executive, 1(3), 207-219. http://dx.doi.org/10.5465/AME.1987.4275740

Siegel, R., Siegel, E., \& Macmillan, I. C. (1993). Characteristics Distinguishing High-Growth Ventures. Journal of Business Venturing, 8(2), 169-180. http://dx.doi.org/10.1016/0883-9026(93)90018-Z

Siegfried, J. J., Sanderson, A. R., \& McHenry, P. (2007). The Economic Impact of Colleges and Universities. Economics of Education Review, 26(5), 546-558. http://dx.doi.org/10.1016/j.econedurev.2006.07.010

Siu, W. S., Fang, W., \& Lin, T. (2004). Strategic Marketing Practices and the Performance of Chinese Small and Medium-sized Enterprises (SMEs) in Taiwan. Entrepreneurship \& 
Regional Development, 16(2), 161-178. http://dx.doi.org/10.1080/08985620410001677862

Smallbone, D., \& Massey, C. (2012). Targeting for Growth: A Critical Examination. International Journal of Entrepreneurship and Innovation, 13(1), 45-56. http://dx.doi.org/10.5367/ijei.2012.0063

Snell, S., \& Bohlander, G. (2013). Human Resource Management. Ohio: Southwestern Cengage Learning.

State Planning Organization (SPO) (2011). Population Census. Retrieved from http://www.devplan.org/Nufus-2011/Tablolar/Tablo\%201.\%20IlceCinsiyet.xls (Accessed on May 01, 2015)

State Planning Organization (SPO) (2013). Economic and Social Indicators. Retrieved from http://www.devplan.org/Ecosos/BOOK/SEG-2013.pdf (Accessed on May 01, 2015)

Steiner, M., \& Solem, D. (1988). Factors for Success in Small Manufacturing Firms. Journal of Small Business Management, 26(1), 51-56.

Storey, D. J. (1994). Understanding the Small Business Sector. London: Routledge.

Surroca, J., Tribó, J. A., \& Waddock, S. (2010). Corporate responsibility and financial performance: The role of intangible resources. Strategic Management Journal, 31(5), 463-490. http://dx.doi.org/10.1002/smj.820

Teng, B. S. (2007). Corporate Entrepreneurship Activities through Strategic Alliances: A Resource-Based Approach toward Competitive Advantage. Journal of Management Studies, 44(1), 119-142. http://dx.doi.org/10.1111/j.1467-6486.2006.00645.x

The Washington Times (2014). Higher education in the Turkish Republic of Northern Cyprus. Retrieved from http://www.washingtontimes.com/news/2014/sep/30/higher-education-turkish-republic-north ern-cyprus/?page=all (Accessed on June 1, 2015).

Thornhill, S. (2006). Knowledge, innovation and firm performance in high- and low-technology regimes. Journal of Business Venturing 21(5), 687-703.

Upton, D. M. (1994). The management of manufacturing flexibility. California Management Review, 36(2), 72-89. http://dx.doi.org/10.2307/41165745

Vorhies, D. W., Morgan, R. E., \& Autry, C. W. (2009). Product-market strategy and the marketing capabilities of the firm: impact on market effectiveness and cash flow performance. Strategic Management Journal, 30(12), 1310-1334. http://dx.doi.org/10.1002/smj.798

Vorhies, D. W., \& Harker, M. (2000). The Capabilities and Performance Advantages of Market-Driven Firms: An Empirical Investigation. Australian Journal of Management, 25(2), 145-172. http://dx.doi.org/10.1108/03090569910292339

Wang, Y., \& Lo, H. P. (2002). Multi-level competition and the integrated hierarchical model 
of competitive advantages in turbulent environments: a resource-based view. Foresight - The Journal of Future Studies, Strategic Thinking and Policy, 4(3), 38-50.

Ward, P. T., Duray, R., Leong, K., \& Sum, C. C. (1995). Business Environment, Operations Strategy and Performance: An Empirical Study of Singapore Manufacturers. Journal of Operations Management, 13(2), 99-115. http://dx.doi.org/10.1016/0272-6963(95)00021-J

Wernerfelt, B. (1984). A Resource-based view of the firm. Strategic Management Journal, 5(2), 171-180. http://dx.doi.org/10.1002/smj.4250050207

Wheelen, T. L., \& Hunger, J. D. (2000). Strategic Issues in Entrepreneurial Ventures and Small Businesses. In: O.A. Shater (eds.), Strategic Management: Year 2000, The New Global Millenium (pp. 283-304). London: Prentice-Hall.

White, G. P. (1996). A meta-analysis model of manufacturing capabilities. Journal of Operations Management, 14(4), 315-331. http://dx.doi.org/10.1016/S0272-6963(96)00096-4

Wiklund, J. (1999). The sustainability of the entrepreneurial orientation - performance relationship. Entrepreneurship Theory and Practice, 24(1), 37-48.

Wiklund, J., \& Shepherd, D. (2003b). Aspiring for and Achieving Growth: The Moderating Role of Resources and Opportunities. Journal of Management Studies, 40(8), 1919-1941. http://dx.doi.org/10.1046/j.1467-6486.2003.00406.x

Wiklund, J., \& Shepherd, D. (2003a). Knowledge-Based Resources, Entrepreneurial Orientation, and the Performance of Small and Medium-Sized Businesses. Strategic Management Journal, 24(13), 1307-1314. http://dx.doi.org/10.1002/smj.360

Wiklund, J., \& Shepherd, D. (2005). Entrepreneurial orientation and small business performance: A configurational approach. Journal of Business Venturing, 20(1), 71-89. http://dx.doi.org/10.1016/j.jbusvent.2004.01.001

\section{Copyright Disclaimer}

Copyright for this article is retained by the author(s), with first publication rights granted to the journal.

This is an open-access article distributed under the terms and conditions of the Creative Commons Attribution license (http://creativecommons.org/licenses/by/3.0/). 